\title{
Spotlights and shadows: Preliminary findings about the experiences of women in family business leadership roles
}

\section{MARY BARRETT}

Professor of Management, School of Management \& Marketing, University of Wollongong, Wollongong NSW, Australia

\section{Ken MoORES}

Professor and Foundation Director, Australian Centre for Family Business, Bond University, Gold Coast QLD, Australia

\section{ABSTRACT}

In an earlier study (Moores \& Barrett 2002) we found successful CEOs had learned leadership of family controlled businesses (FCBs) in a series of distinct learning phases. Because that study's sample did not include many women, our present study focuses on women in FCBs to better understand how they exercise leadership and entrepreneurship in the family firm context. Case study analysis of an international sample of women FCB leaders, using frameworks which avoid essentialist assumptions about women's and men's approach to leadership, suggests there are some characteristic ways women leaders learn FCB leadership and entrepreneurship roles. We have tentatively labelled them stumbling into the spotlight, building your own stage, directing the spotlight elsewhere, and coping with shadows. Some interviewees had failed to attain leadership; we labelled their journey becoming invisible. This paper uses Eisenhardt's (1989) framework to elaborate on the stumbling into the spotlight and coping with shadows journeys and what can be learned from them.

Keywords: women, family business, learning, leadership, roles, entrepreneurship

\section{BACKGROUND: WOMEN, FAMILY BUSINESS AND ENTREPRENEURSHIP}

T here are several reasons why understanding more about women leaders of family controlled businesses (FCBs) can help our understanding of family business in general. First, contrary to common perceptions of family businesses as slow-moving and lacking in innovation, they are increasingly being recognised as the source of many new entrepreneurs (Craig \& Lindsay 2002; Craig et al. 2006; Dibrell \& Craig 2006). In addition, Habbershon \& Williams (1999) and Miller \& Le Breton-Miller (2005) argue that successful family firm owners and managers typically leverage various forms of family-based relatedness, or 'familiness', for competitive advantage. Given that FCB women are more likely than in the past - and more likely than 
non-family firms in the present - to achieve leadership of their firms (Dugan et al. 2008; Evans 2005; Mass Mutual Financial Group 2007; Nelson \& Levesque 2007), it is important to understand how all members of FCBs, including women, contribute to FCBs' entrepreneurial activities. However investigating women's experiences in FCB leadership roles is complex, not least because researchers define FCBs and entrepreneurship in many different ways. Debates about how gender roles are acquired, the influence of national culture on women's entrepreneurial profile, and conflicting philosophical approaches to men's and women's different position in business and society also present particular challenges. These issues are discussed briefly below.

\section{Varying definitions of FCBs}

Westhead \& Cowling (1998:34) summarize the many definitions of FCBs used in previous research. As they demonstrate, the scale of family firm activity in a developed economy is highly sensitive to the FCB definition selected, something that policy makers, practitioners and researchers need to keep in mind if they are to avoid confusing 'demographic sample' differences with 'real' differences when comparing family and non-family firms. Litz (1995) has reduced the definitional complexity by grouping FCB definitions into two complementary approaches: a structure-based, 'components of involvement' approach and an intention-based, or 'essence' approach. The components of involvement approach consider elements of family involvement such as the proportion of equity the family holds. The intention-based approach is based on the values and preferences of the family firm's members towards family-based relatedness. While components of involvement are usually easy to measure, the variety of possible measures makes comparing research findings difficult. The intention-based approach allows FCB members' perceptions of what a family business is to become the starting point for investigating FCBs' distinc- tiveness. Since we aim to build theory about what the FCB context means for its women leaders, such an approach has obvious advantages. Westhead and Cowling (1998:50) recommend that researchers choosing only one FCB definition choose the following: (a) more than $50 \%$ of ordinary voting shares are owned by members of the largest single family group related by blood or marriage; and (b) the company is perceived by the Chief Executive, Managing Director or Chairman to be a family business. The firms we chose for this study conform to this definition.

\section{Varying concepts of entrepreneurship}

Another problem, as Bull and Willard (1993) have noted, is that we lack a unifying economic theory of entrepreneurship. Similar difficulties arise with theories of leadership. What we do know about entrepreneurship, according to Ogbor (2000), is derived from Schumpeter's theories of 'creative destruction', the theories of enterprise creation provided by Collins and Moore (1964), and Knight's (1921) theory of risk. These theories all point to opportunity recognition and innovation as the defining features of entrepreneurial action. Accordingly, following Chrisman and Sharma (1999: 18), for our purposes 'entrepreneurship' includes both creating a new organization in response to an opportunity, and instigating innovation within an existing organization.

\section{Gender differences}

There is considerable debate about why women's position in business and society differs from that of men. The social learning approach to gender roles (e.g. Bussey \& Bandura 1984) holds that differences result from cumulative experience. Social agents such as parents, teachers and peers shape children's gender-specific behaviours by reinforcing gender-appropriate behaviours and punishing gender-inappropriate behaviours. Other researchers such as Best \& Williams (1997) argue that social learning alone cannot explain children's behaviours which do not simply imitate 
people around them. Proponents of cognitive development theory (e.g. Ruble 1987; Semin \& Zwier 1997) argue that children progress through stages of understanding in acquiring gender knowledge, which shapes their subsequent experiences. Semin \& Zwier (1997) have found cognition to be effective in explaining work-related gender differences which appear in many different societies.

\section{The influence of national culture on women's entrepreneurial profile}

Cognitive development theory has been extended to studies of entrepreneurship, with cognition proposed as the intermediate variable in the association between national culture and entrepreneurial orientation (Busenitz \& Lau 1996; Mitchell et al. 2002). Hofstede's (1980; 1998) cultural constructs, including masculinity, have been taken up in many empirical studies of national differences in entrepreneurship. Hofstede (1980:190) defines masculinity as 'assertiveness interests' such as earnings or advancement, contrasting it with femininity, or 'interest in relationships, cooperation, and atmosphere'. Research findings (e.g. McGrath et al. 1992; Makino \& Neupert 2000; Mueller \& Thomas 2000) associate high masculinity at the national level with higher measures of entrepreneurship, and high gender differentiation with women having a lower entrepreneurial profile. Problems arise because of the definitional issues of entrepreneurship mentioned earlier, and because research samples have been skewed towards men, obscuring possible differences between men's and women's responses to the cultural environment.

\section{Conflicting philosophical assumptions}

Closely linked to these debates, researchers have used different, sometimes conflicting philosophical assumptions when exploring gender issues in management and leadership. One approach, social feminism, holds that women and men have different experiential backgrounds and therefore different - but equally valid - ways of thinking and learning for entrepreneurship (Fischer et al. 1993). An alternative approach, liberal feminism, assumes that gender difference has resulted in inequality and that one or both genders need to change their behaviours (Greer \& Greene 2003; Hurley 1999). Liberal feminism underpins many previous studies of the 'glass ceiling' in FCBs (e.g. Cole 1997; Dumas 1989, 1990, 1992; Hollander \& Bukowitz 1990; Iannarelli 1993; Lyman 1988; Salganicoff 1990; Sexton \& Bowman-Upton 1990; Vera \& Dean 2005). Ahl (2004) argues that social feminism and liberal feminism both wrongly assume that women and men are essentially different, and that researchers should direct more attention to contextual factors influencing men's and women's differing entrepreneurial profiles. The present study takes up Ahl's suggestion (2004).

\section{The value of a case approach and gender neutral frameworks}

These controversies and the relatively unexplored nature of women's entrepreneurship in FCBs suggest a case study approach. Case studies help researchers looking at new topic areas to build theories that are novel and testable (Eisenhardt 1989). They are also an excellent way to study a subject's 'lived experience' (Silverman 1985; Yin 1984). To avoid problems of gender essentialism, we were careful to choose gender-neutral analytical tools, that is, models of learning, familiness, and business roles which assume neither that women's experiences are similar to nor different from those of men. The three frameworks we used are explained briefly below.

\section{PhASES OF FAMILY BUSINESS LEARNING}

In an earlier study (Moores \& Barrett 2002) we found that successful CEOs in FCBs had learnt leadership in four phases: L1 learning business, L2 learning our business, L3 learning to lead our business, and L4 learning to let go our business. Each learning phase involved dealing with a specific paradox arising from the nexus of 'family' and 'business'. Learning business (L1) requires the potential heir to leave the family firm to learn 
functional business techniques and the personal discipline needed for business. While crucial for the future of the FCB, the heir's departure is nevertheless a threat to its continuity as a family firm. The pathway through the paradox is simple: leave anyway. Learning our business (L2) means learning the special qualities of the family business, while 'continuing the firm differently' in the interests of its development. The pathway through this paradox is to keep the firm's philosophies rather than the details, and to know the market value of being a family business. Learning to lead our business (L3) means acquiring a 'helicopter view' of the firm and its life cycle stage, so as to plan for its future. Its paradox comes from the need to formalise the firm as it grows, yet maintain its informal qualities of 'familiness'. We found no single pathway through this paradox: every leader had to forge an individual path. Learning to let go our business (L4) requires CEOs to 'lead for leaving': to anticipate the firm's needs once they have stepped down, to plan a productive non-leadership role for themselves, and to manage family members' varied ambitions with respect to the firm's future. The pathway through this paradox is to develop a timeline for retirement, create management development systems, and to stick to the plan.

\section{COMMUNITIES OF PRACTICE}

Since the crucial work of Lave, Wenger and Orr on communities of practice (e.g. Lave 1988; Lave \& Wenger 1991; Orr 1996), scholars have explored the vital contribution they make to organizations. They have been argued to be the source of organizational learning which supports innovation (Brown \& Duguid 1991), repositories of disciplinary knowledge (Orr 1996), and modes of governance both within and among organizations (Grandori 2001). There are also resemblances between how communities of practice promote organizational learning and the ways the familiness ${ }^{1}$ qualities of family business promote competitive advantage. For example Wenger (2000) argues that healthy learning communities need learning energy, trust and self-awareness. These dimensions are enhanced by attention to three specific 'modes of belonging': engagement (working together to solve problems), imagination (sharing a vision of the future), and alignment (sharing a purpose). Yet an excess of familiness ('constrictive' familiness) may actually harm the firm (Chrisman, Chua \& Steier 2005). Again, links between managing communities of practice and FCBs are apparent. For example, an FCB's capacity to learn (its learning energy) suffers if it employs family members when it needs external expertise. The way a founder imagines the future of the firm may overlook junior family members' hopes, leading to a failure of trust at succession. An FCB's self-awareness - the way its conscious or unconscious idea of itself is reflected in its practices - may undermine its success if members' sense of shared purpose becomes too entrenched. For example, an FCB's practices may reflect its members' shared dedication to product quality, but this focus may lead them to overlook the need for marketing to head off a competitor. Given these practical resemblances between communities of practice and FCBs, we looked to see whether a particular mode of belonging dominated our interviewees' approach to learning in the FCB.

\section{FAMILY BUSINESS: WOMEN'S ROLES}

In her study of Brazilian FCBs, Curimbaba (2002) distinguished three typical roles for daughters ('heiresses') in family firms: Invisibles, Anchors and Professionals. The Invisible family business woman is typically part of a large nuclear family with many sons. This means the daughters are not included in management succession plans. 'Invisibles' have difficulty identifying with managers or entrepreneurs, regarding the FCB as

1 The construct of familiness is still being defined. In the present context we are focusing on familiness as a form of social capital (e.g. Arregle et al. 2007). However Sharma (2008: 974) points out the need to incorporate other forms of capital - human, financial and physical - into the familiness construct. 
a stock of accumulated wealth that they should not be prevented from enjoying. Their invisibility encourages them to leave the FCB and come back as they wish. Anchors come from families with predominantly female offspring, with few men in any generation. With great visibility inside the FCB, they became essential for its continuity, despite passing through phases that tend to reduce their significance. They readily adopt the company's spirit but occasionally become confused between their own objectives and those of the company. Professionals work in mature family companies with complex ownership structures, where a reasonable number - but not a majority - of men also work. They typically join the family company when they can make a particular contribution to it, often to resolve a family conflict, but after that no-one pushes their careers further. In their belief that the concept of merit is universal, valid and clear, they always try to separate family from business, which sometimes leads them to fall foul of others' political tactics.

\section{A new role: Entrepreneur}

Curimbaba identified that some movements between roles are more explicit and likely to be recognized as entailing an aspiration towards leadership, such as the movement from being an Invisible to a Professional or an Anchor. Other moves are subtle and occur discreetly over time. While acknowledging that some movements between roles are directed towards leadership, Curimbaba did not focus on women who start new ventures, or who act entrepreneurially in an existing FCB. This is because her project was focussed on issues of birth order on women of the second generation or later working in FCBs. However, according to our intention-based definition of an FCB, new, first generation ventures may equally be classed as family firms if the founder sees them as such. To encompass the experiences of women who start new ventures they see as family firms, or who act entrepreneurially in an existing FCB, we posit the new role of Entrepreneur.

\section{MethOD}

Our research uses Eisenhardt's (1989) eight-step case method. To link these steps with the conventional presentation of a research paper, we deal with the first four steps: 'getting started', 'selecting cases', 'crafting instruments and protocols', and 'entering the field', under Method. 'Analysing data' appears under Analysis, 'shaping propositions' and 'enfolding literature' comprise the Results section, and the remaining step, 'reaching closure', appears in Conclusions, Implications and Further Research. Since our analysis also involves comparing results with previous findings, some literature is also 'enfolded' in earlier stages.

\section{Step 1: Getting started}

This phase defines the broad research question and possible constructs (Eisenhardt, 1989: 536). Whetten (1989) takes a similarly broad approach, arguing that the essential ingredients of a valueadded theoretical contribution are explicit treatments of Who, What, Where, When and, most importantly, Why and How questions. Our research agenda asks what entrepreneurial and leadership roles women play in FCBs, and how women acquire the skills for FCB leadership. Eisenhardt (1989:536) also insists on the need to maintain 'a clean theoretical slate' at this stage. As discussed earlier, an important way we do this is to use gender-neutral analytical tools.

\section{Step 2: Selecting cases}

We approached potential participants at FCB conferences, and via business and other networks. We sought out FCB founders and CEOs whom we expected to exemplify the phenomena under investigation: leadership and entrepreneurship. We also included 'stretch' or 'limiting' cases: FCB women who were neither founders nor CEOs but whom others - other FCB leaders - perceived to be leaders and entrepreneurs. Including CEOs who had succeeded to leadership after an older generation family member had stepped down enabled us to include the traditional focus on FCB succession. Finally, to see whether and how 
issues for women's leadership in FCBs might transcend boundaries of national culture, the sample included participants from diverse national backgrounds including North America, Hong Kong, the Middle East, France and Australia. A snapshot of our sample, categorised by founder/non-founder, and CEO/non-CEO status of the participants, appears in Table 1.

TABle 1: PARTICIPANTS BY FOUNDER/NON-FOUNDER AND CEO/NON-CEO STATUS

\begin{tabular}{lcc} 
& Non-CEOs & CEOs \\
Founders & Brenda, & Jane, Elle \\
Miriam, & Deborah & Nancy, Hannah \\
Non-founders & $\begin{array}{l}\text { Felicity, Sue, } \\
\text { Gloria, Cass }\end{array}$ & Robyn, Ingrid \\
& \\
\hline
\end{tabular}

We gathered case data from 16 women and found after analysing 13 cases that we had reached data saturation - that is, a point when no new patterns or themes were emerging. The 13 participants were drawn from 12 FCBs: two third-generation firms (Sue, Felicity), four second-generation firms (Gloria, Ingrid, Robyn/ Deborah, and Hannah), and six first-generation firms (Brenda, Cass, Ellen, Jane, Miriam, and Nancy). Five FCBs employed more than 100 people (Brenda, Robyn/Deborah, Sue, Cass, and Ingrid), two employed between 20 and 100 people (Felicity, Gloria), with the remainder employing fewer than 20 people. The two non-CEO founders have both been succeeded by a family member, one of whom, Robyn, is part of the sample. Participants who were current CEOs of businesses they had founded included women with a family business background and women without a family business background.

\section{Step 3: Crafting protocols and Step 4: Entering the field}

Participants were interviewed at their workplace, their home or some other private venue. We asked each interviewee simply to tell us her story, how she had got to where she was. In that way we avoided 'priming' the participant in one thematic direction or another. Consistent with Eisenhardt's 'clean theoretical slate', our aim during the interviews was to understand each participant's experience of her place in her FCB. The interviews, each of which lasted from 1.5-3 hours, were recorded then transcribed and entered into the NVivo program, a software tool for analysing qualitative data.

\section{ANALYSIS \\ Step 5: Analysing data}

We coded each participant's story first according to the issues she raised, then according to factors thought to influence women's propensity to exercise entrepreneurial and leadership roles in FCBs, such as having a family business background. We also analysed the data using the learning three frameworks explained in the previous section. This allowed us to group the cases and develop general research propositions according to the thematic similarities and differences that recurred within and between cases.

\section{RESULTS}

\section{Step 6: Shaping propositions ${ }^{2}$}

Our analysis suggested four ways women move onto the FCB leadership stage:

1. Stumbling into the spotlight

2. Building your own stage

3. Directing the spotlight elsewhere

4. Coping with shadows

Stumbling into the spotlight concerns the experiences of women who unexpectedly find themselves leading the family business, whether through the founder's death, or because the interviewee felt starting a firm was the only way to

2 We prefer the term 'propositions' to Eisenhardt's 'hypotheses', as we aim to produce broad results rather than directly testable questions. 
meet a particular need in society. Building your own stage considers women who have an FCB background but are either prevented from leading the original FCB or prefer to create their own firm. Directing the spotlight elsewhere groups interviewees who lead the family firm precisely by not appearing to do so. Coping with shadows describes FCB women who deal with the legacy of an earlier leader. A fifth relationship with the family business stage also emerged, reflecting the experiences of women who recognized that, despite earlier hopes, they had never really attained leadership, having lost the battle or given up the struggle. We labelled this experience 'Becoming invisible'. We now examine closely two broadly contrasting routes to leadership: Stumbling into the spotlight (Brenda and Deborah), and Coping with shadows (Ingrid and Robyn). The resemblances and contrasts within and between these two sets of cases suggest answers to some of our research questions.

\section{StUMBLING INTO THE SPOTLIGHT}

\section{Brenda}

Brenda succeeded to the leadership of the family motor dealership when her husband died suddenly. Because she had no business background, training or experience, both Brenda and her husband had seen her purely as a 'support person'. Learning to lead the FCB after his death was short, sharp and difficult. Brenda felt she had stumbled inadvertently into a blinding spotlight where her mistakes would be obvious. Her 'audience' was hostile: she experienced overt discrimination from men in business and ostracism from their wives. Even her friends told her to 'just go and get some nice little job somewhere'. She knew the business needed debt reduction and growth, but had little idea how to achieve this. Brenda's solution was to build on her female skills as a housewife where, as she says, 'You become a bit of an economist'. She also asked the staff for their ideas, a radical approach in the motor industry in the 1970s:
Brenda: I had debts to pay and wages to meet, the overheads were high. I had the opportunity of encouraging them [the staff] to get a bigger bottom line and discussing, how can we do it? Where can we cut corners?

Her major strategy for ensuring the firm survived was to simply build equity in the business faster than other dealerships:

Brenda: I was paying the debts back quicker than I had to. And I was taking the profits and putting them into debt reduction and growth. I thought to myself, well, this is great because that property has got to grow into something that's worthwhile. If I wanted to grow, I had a better chance of getting another loan. So, it worked.

Nevertheless it was a long time before Brenda felt she had the full confidence of other firm members and her firm's network organization. In fact, Brenda recalls that she never felt she could say, 'I don't need to worry about these bastards anymore. I'm on top of this'.

Brenda is one of only two participants in the study to have completed the generational succession process. She had a clear idea about which of her children would be best suited to running the firm and stuck to this, managing the 'inevitable jealousies' with his siblings. She was equally resolute about exercising her prerogative to make a transfer decision based on the market value of the firm. She has truly retired from the business, something many FCB founders never achieve. However, Brenda continues her involvement in the business as a kind of ambassador for it, a positive means by which a departing leader can manage the exit process (Sonnenfeld 1988).

\section{Deborah}

Deborah founded a home-care business when she was a first-time mother. It now operates nationwide. Like Brenda, she had never planned to open a business: 
Deborah: I had a six-week-old baby, I wasn't about to start a business. It [the idea for the home-care service] just grabbed me and said this is what has to be done, you have to do it.

While Deborah strongly believes there is a need for a home-care service, at first she did not recognise it as a business opportunity. She tried every other way she could think of to get the service started and only started the business when her husband told her she was the only person who could do it. Brenda's friends had been scathing about the idea of her running a business and Deborah's friends were equally sceptical. Again like Brenda, Deborah's direct business experience had been limited to a support role in her husband's firm. Her father and uncles had also run a business, but Deborah mainly recalls her father's lack of attention to planning and the problems this created. As a result, Deborah has made planning a mainstay of her management philosophy.

Nevertheless Deborah is amazed the firm has grown enough to continue after her departure and only gradually realizes she needs to deal with succession systematically. She eventually settles on her third daughter, Robyn, after trying out each of her daughters in the firm and encouraging those whose performance does not match her 'familiness' values to leave. We see this played out in the clash with her second daughter:

Deborah: She [Deborah's second daughter] and I are temperamentally different and after two years she said, 'You know what I'd do? Sack the lot of the staff. You and I could run this show on our own.' And I said, 'Well, that's not really the way to run a business.' She said, 'Well, I can't stand it. You mollycoddle them, you look after them.' She said, 'I'd sack the lot.' So I thought, this is not going to work. So I said to her, 'You cannot do that, you can't have that attitude in front of the staff.' So we agreed to disagree and she went off to do her thing....
Robyn, by contrast, accepts her mother's approach to business, including her so-called 'mollycoddling' management style - which might be called developing familiness. She continues Deborah's approach, but just a little differently to allow time to expand the firm and work on its strategic direction:

Robyn: I've made lots of changes in the last twelve months, significant changes in operations. But that wasn't because I felt that Deborah was doing anything incorrectly or wrongly. But in the time I had I was able to observe and I was trying to think of how we could become more profitable. I've got additional staff, put on an operations manager and a chief financial lass who have taken a lot of my other work which I was doing prior to Deborah's stepdown as CEO.

Deborah is the only other participant to have completed generational succession. While she tried out each of her daughters as a possible successor, she had never created a precise timetable for the handover. In fact, 17 years passed between when Robyn entered the firm and when she took over its leadership, and in that time Robyn never once asked Deborah when she would step down or even discussed whether she might eventually lead the firm. While in other cases such a prolonged silence about succession would indicate difficulties, with Deborah and Robyn it demonstrates an unusual level of trust.

\section{COPING WITH SHADOWS}

\section{Ingrid}

Ingrid is the second generation CEO of a large agricultural machinery and real estate business in the United States. Despite her title, she seemed to be still on trial as leader. Her journey to her current position had taken many years, with frequent exits and re-entries to the FCB. Unlike Brenda and Deborah, Ingrid recalls spending time on her father's business premises as a child where she fell in love with the firm's product: 
farm machinery. But she also associates this time with seeing little of her father:

Ingrid: In the mornings he was still sleeping when we went to school and in the evenings he wouldn't come home until after we were in bed. Sometimes we saw him on the weekends. Sometimes he'd drop us off at a rock pit and let us play for a while. We didn't have much interaction.

Ingrid's parents divorced when she was 11 . Since then her family has experienced major conflict, alcohol and drug abuse, and serious illness for more than 40 years. Ingrid attributes the conflict to her father who, in her view, was 'brilliant in the business sense, but very destructive when it came to people and family relationships'. At first the family conflict made Ingrid determined not to enter the family business. She dropped out of her university course in her computer systems, only completing her studies years later after several exits from the FCB. She gets a job in the hotel industry, which she finds exciting and a quick way forward:

Ingrid: I worked my way up in the hotel business. I was having fun and loving it. I went from a front desk clerk to a front desk assistant manager and was responsible for training the front desk cashiers and clerks. I then became a night auditor, then I was in charge of payroll. Then I was promoted to personnel payroll [...] We had about 700 employees.

Later, Ingrid's father, whose combative nature meant he was fast running out of potential successors, offered her large financial incentives before she would even consider joining the firm. Her eventual decision to do so reignites conflicts between other family members, and all of them have to dodge their father's attempts to make them compete with each other for rewards such as a higher paid role. He also randomly selects individuals as scapegoats:

Ingrid: We called it 'being in the slot'. You could tell who was in the slot because that per- son couldn't breathe right. If my dad said he wanted XYZ and you showed up with XYZ, he was mad because you didn't bring $A B C$ and why didn't you know to bring $\mathrm{ABC}$.

Even carrying the family name creates problems:

Ingrid: ...I would walk into rooms and conversations would stop. I couldn't really form friendships with anybody because they were all afraid that I was going to run and tell Dad things.

It also means Ingrid has few opportunities to talk with others to find out how the firm works. Ironically, the network distributor organization of which Ingrid's firm is a part, prefers family-run firms because it believes their continuity and contribution to their local communities add to their market value. When Ingrid gains the dealer network's support to lead the FCB's farm's machinery division, she adopts a 'stewardship' mindset: 'just overseeing the firm for the next generation', as a way of reducing personal stress. The unhealthy ways family and business are entwined mean that for Ingrid, creating 'familiness' means reducing the distractions of family mixed with business deliberations:

Ingrid: The first thing I am working on is separating the family from the business and putting a structure in place that allows the family to do its job, which is a very different job than what the business has to do.

However the strain of doing this reduces Ingrid's confidence as a leader and delays her efforts to determine the business's long-term direction. This situation is only now starting to change, but it is too early to judge whether her plans will bring results.

\section{Robyn}

Robyn presents similarities but also some important differences from Ingrid in how she copes with the founder's shadow. Like Ingrid, Robyn was at first reluctant to enter the family business, not for negative reasons, but because she had 
already spent so much time there. As Deborah relates it:

Deborah: She [Robyn] said, 'I am going to be the only one of your daughters that is not involved in the business.' So I said, 'Great, who cares'. I mean, I didn't care. I wasn't building an empire. [...] I was doing it on my own. If my kids were interested that was fine. If they weren't interested that was fine too.

Robyn's mother says she had to encourage her daughter's belief in herself, but Robyn disagrees, saying that even when she left school she knew she was 'good with people and at managing things'. Rather than starting university and risking failure, like Ingrid she begins working in the hotel business. This reinforces her confidence as a manager and starts her thinking along entrepreneurial lines:

Robyn: I enjoyed the various aspects of the hotel but I also realized that I could see holes in the staffing issues and things like that and thought I should run my own hotel. You know maybe get a little $B \& B$ and do it myself the way I think it should be done.

Later, during what she thought would be a temporary stint in her mother's firm, Robyn learned the business thoroughly. She took time to listen to the staff and work with them to solve problems:

Robyn: And I would go and sit with them and I would talk to them about their procedures. There were things that they were doing that were going round in circles. And I thought if they could cut out a few procedures but yet get the information that they needed...

In contrast to the fraught communication patterns of Ingrid's family, Deborah and Robyn are almost eerily close. They each know what the other is thinking, finish each other's sentences, and create a level of familiness which encompasses staff as well as family members. While Robyn spends 17 years in her mother's shadow, she enjoys a smooth entrance onto centre stage, with Deborah handing over the $\mathrm{CEO}$ role in a formal ceremony. Ingrid, in contrast, had to deal with her FCB's politics and manage her own ambivalence about leading.

\section{Step 7: Enfolding the literature}

Answers to our research questions, summarized as: 'What entrepreneurial and leadership roles do women play in FCBs and how do they learn them?' begin to appear when we compare these two routes to leadership. Our three analytical frameworks reveal the contrasts and occasional similarities between them.

\section{FAMILY BUSINESS LEARNING PHASES}

\section{Compressed Learning}

Brenda's and Deborah's learning phases are compressed and carried out in a different order from the L1 $\rightarrow \mathrm{L} 4$ sequence we found typical for men. Having stumbled into the leadership spotlight without an outside learning phase (L1), Brenda and Deborah are improvisers rather than method actors who have rehearsed their roles. In L2, learning our business, both create the distinctive cultures of their firms as they go along, making them staff-centred, a startling innovation in the eyes of some observers. Leading our business (L3) means achieving firm legitimacy, which Zimmerman \& Zeitz (2002:414) define as a 'social judgment of acceptance, appropriateness, and desirability'. It is a vital resource for new ventures because it helps overcome the 'liability of newness' (Stinchcombe 1965) which sinks so many not-yet-profitable ventures. Formal qualifications, accreditations, testimonials and so on help new firms present themselves as legitimate players in the market. Neither Brenda nor Deborah has these credentials, and their gender also detracts from their legitimacy as firm leaders. So they are under unusually strong pressure to make their firms profitable.

\section{Extended learning}

Learning in the shadow of a founder is a lengthy affair by comparison with stumbling into the spotlight. Ingrid and Robyn both enter the FCB 
reluctantly, uncertain what to do with their lives. They have gained early experience outside the FCB (L1), but then some aspects of their learning diverge. Ingrid joins the FCB almost against her better judgement; she says now that dropping her business studies had been a way of postponing the moment even further. Robyn however sees her mother's firm as a refuge where she can find her life goals; she discovers them in improving the firm's operations and strategies. Both Ingrid and Robyn 'continue their firms differently' (L2). However, working out how to manage differently and persuade family members to 'hear reality' is virtually Ingrid's entire task, whereas Robyn quickly gets to work on the leadership and entrepreneurial tasks of expansion and system development (L3). Ingrid sees her leadership role (L3) primarily as one of stewardship. The conditions of stewardship typically include high levels of family identification with the enterprise, shared and aligned values between the family and the business, and an orientation toward the long-term success of the firm (Corbetta \& Salvato 2004; Davis et al. 1997). Ingrid's version of stewardship suggests she will orient herself towards long-term success of the firm but is reluctant to identify herself too much with the enterprise at a personal level.

\section{COMMUNITIES OF PRACTICE}

\section{Building learning communities}

Neither Brenda nor Deborah does much learning in a pre-existing learning community; both had been simply 'support people' in their husband's firms. Later, learning from other business learning communities (e.g. through 'boundary crossing' (Wenger 2000)), is impossible because of the scepticism and direct opposition they encounter as business women. Even now their rapid, unplanned introduction to the FCB means they lack a 'learning trajectory' (Wenger 2000:241). Brenda and Deborah build their own learning communities, but differ in their preferred 'mode of belonging'. Brenda favours engagement: doing things with her staff and encouraging them to share responsibility with her. The staff decide who should be part of their community - they even carry out any sackings. This is typical of the 'boundedness of engagement', that is, how the community defines actions as competent (Wenger 1999:175). Deborah on the other hand favours imagination. The scepticism she encounters from her friends and the negative business role models in her family reinforce her business idea, build her vision of the firm, and shape her management philosophy.

\section{Managing older learning communities}

Robyn and Ingrid also select contrasting modes of belonging, partly in response to their firms' histories. Robyn leads a strong learning community, which she had already helped create through engagement: sharing and solving problems with other staff. In contrast, Ingrid often mentions her FCB's 'unhealthy dynamic'. Against a background of lawsuits, secret deals, even embezzlement by firm members, it has been extraordinarily difficult for members to carry out the work of engagement: working together to decide how the firm should function. Shared interactions have given rise to strange, negative forms of self-awareness such as 'being in the slot': family-speak for being a scapegoat. Because members lack experience in working together, Ingrid focuses instead on imagination: devising vision and mission statements with which the firm can present a new idea of itself to its members and outside stakeholders. However, members' inexperience with working together also means activities that develop the learning community are not widely distributed: Ingrid alone is doing the work of thought leader, networker, the person who documents the practice, and so on (Wenger 1999; 2000).

\section{EVOLVING ROLES}

\section{From invisible to anchor to entrepreneur}

Brenda and Deborah both run first generation firms which they see as FCBs 'by intent'. This means neither is an 'heiress': Curimbaba's term 
for women managers - not leaders - in FCBs started by a forebear. Neither had ever expected to lead a business; in that sense both were originally Invisibles. But even then Brenda took calculated risks: she rather than her husband negotiated the bank loan with which they started the dealership. Her husband's death makes her an Anchor, but she soon develops an entrepreneurial role, moving the firm towards profitability. Deborah also started her own firm despite being slow to recognise her business opportunity, and was always its Anchor, defining her personal goals in terms of the firm and unconcerned whether anyone else would join her. She develops the firm to fit her vision, but remains reluctant to acknowledge its growth. This may be a way of coping with being 'condemned to success' and tied to the business: both common problems for Anchors.

\section{From professional to entrepreneur}

Ingrid and Robyn initially exemplify Curimbaba's Professional role. Both have worked outside the family firm and could do so again if necessary. However, on entering the FCB Ingrid struggles with its political side - a typical and exhausting problem for Professionals - she tries to separate family from business, attempting to solve business problems which have developed from multiple family conflicts. Both Ingrid and Robyn are Entrepreneurs, aiming both to renew and expand their firms, but Ingrid's plans are still in the early, untested stages. Robyn, in contrast, began expanding the firm while her mother was still in charge. Unexpectedly perhaps, given Professionals' supposed independence and awareness of their value on the external employment market, they do not necessarily fare better than Anchors or Invisibles in achieving FCB leadership.

\section{CONCLUSIONS, IMPLICATIONS AND FURTHER RESEARCH}

\section{Step 8: Reaching closure}

Our analysis yields some propositions which other researchers may wish to test further. First, our findings suggest that both new and established family enterprises demand leadership and entrepreneurial input. However while women may be more likely than in the past to assume FCB leadership roles, they are less often being systematically groomed for leadership. Their learning phases were often disordered or disrupted. In our entire sample, only Robyn followed the four phases of learning in the steady $\mathrm{L} 1 \rightarrow \mathrm{L} 4$ sequence which our earlier study (Moores \& Barrett 2002) found was typical for men. However, bearing in mind the comments of Westhead \& Cowling (1998) on the effects of FCB definitions, this finding may be influenced in part by the broad, intention-based definition of family business we have used in this study. FCBs defined according to a different, narrower configuration of family involvement factors may yield a different picture of women's inclusion in succession practices.

Second, we posit that FCBs which project that a 'learning presence' engenders successful journeys to leadership, however long they take. However the source of the learning presence varies. Robyn's experience of coping with a founder's shadow suggests that the major source of learning may be an individual, such as the incumbent CEO, but Ingrid's experience was that the incumbent $\mathrm{CEO}$ hindered her learning. The 'learning presence' may also be located within a team or even the firm as a whole. Lacking positive role models elsewhere, Brenda and Deborah used their entire firms as learning tools. A similar variability may characterize learning at the level of the FCB. As Birdthistle \& Fleming (2005) point out, FCBs have an inherent disposition to be learning organizations, but our analysis indicates FCBs do not all learn in the same way. Brenda's and Robyn's choice of engagement, or shared problem-solving, to promote learning in the firm continues the tradition they had established earlier. However because in Deborah's and Ingrid's firms there is no such tradition, imagination is a better choice. Brenda and Robyn plunge into problem-sharing; Deborah and Ingrid first create a personal vision of the firm's future which they try to persuade others to 
implement. Further research could look at the aspects of FCBs' history which serve as antecedents and consequences for the dominance of a particular mode of learning.

Third, our findings also accord with the growing conviction in the research community that there are more useful and valid research tasks than trying to identify inherently 'male' or 'female' approaches to leadership and entrepreneurship. Brenda, Deborah, Ingrid and Robyn all tried to create more communal relationships within their FCBs. In fact some regarded this as evidence of the female qualities of their management style. Nevertheless Brenda and Deborah, who were the only participants to have handed over leadership to a successor, did so using approaches no different from those used by the male FCB leaders in our previous study (see Moores \& Barrett 2002). Their approach to succession, which places the longevity of the community above individual interests, also suggests there is a need to investigate how leadership and entrepreneurship play out within organizational communities - not just how these roles present themselves as the personal dramas of individuals.

Fourth, our findings suggest a new avenue for exploring the role of national culture in women's entrepreneurship. Elsewhere in the study we found that FCB women from the Middle East (Lebanon, Egypt) where gender roles are highly differentiated and where women have traditionally been less likely to act entrepreneurially (Metcalfe 2006; 2007) were nevertheless among those who 'built their own stages'; that is, started their own firms separately from the original FCB. It may be that FCBs in high gender differentiation countries, which usually have low levels of female entrepreneurship, create learning experiences which FCB women may use to start new, separate firms. This is an issue which large-scale studies could explore.

Finally, the 'familiness' of the FCB presents some special pressures for women - and many women in our sample are developing special solutions. These solutions may not be limited to women-led firms. This is not to suggest that the strategies women develop are always or even usually better than men's - but simply that a wide range of ideas does help to yield good results. Understanding women's responses to the constraints, demands and possibilities of FCBs promises many absorbing dramas to come.

\section{ACKNOWLEDGEMENTS}

The authors thank the reviewers of earlier drafts of this paper for their useful suggestions. They also thank the management consulting firm BDO Kendalls for its financial support.

\section{References}

Ahl H (2004) The Scientific Reproduction of Gender Inequality: A Discourse Analysis of Research Texts on Women's Entrepreneurship. Liber: Copenhagen Business School Press.

Arregle J-L, Hitt MA, Sirmon DG and Very P (2007) The Development of Organizational Social Capital: Attributes of Family Firms, Journal of Management Studies, 44: 73-95.

Best DL and Williams JE (1997) Sex, gender and culture. In Berry JW, Segall MH and Kagitcibasi C (Eds) Handbook of Cross-Cultural Psychology Vol 3: Social Behavior and Applications. Needham Heights MA: Allyn and Bacon, pp 163-212.

Birdthistle N and Fleming P (2005) Creating a learning organization within the family business: an Irish perspective, Journal of European Industrial Training 29: 730-750.

Brown JS and Duguid P (1991) Organizational learning and communities of practice: Toward a unified view of working, learning and innovation, Organization Science, 2: 40-57.

Bull I and Willard GE (1993) Towards a theory of entrepreneurship, Journal of Business Venturing 8: 183-195.

Busenitz LW and Lau C-M (1996) A CrossCultural Cognitive Model of New Venture Creation. Entrepreneurship: Theory \& Practice 20: 35-39.

Bussey K and Bandura A (1984) The influence of gender constancy and social power on sex-linked modelling, Journal of Personality and Social Psychology 47: 1292-1302.

Chrisman JJ, Chua JH and Steier L (2005) Sources and consequences of distinctive familiness: An introduction, Entrepreneurship: Theory \& Practice 29: 237-247. 
Chrisman JJ and Sharma P (1999) Toward a reconciliation of the definitional issues in the field of corporate entrepreneurship, Entrepreneurship: Theory \& Practice 23: 11-27.

Cole P (1997) Women in family business, Family Business Review 10: 353-371.

Collins OF and Moore DG (1964) The Enterprising Man. East Lansing MI: Michigan State University Press.

Corbetta G and Salvato C (2004) Self-serving or self-actualizing? Models of man and agency costs in different types of family firms: A commentary on 'Comparing the agency costs of family and nonfamily firms: Conceptual issues and exploratory evidence', Entrepreneurship: Theory \& Practice 28: 355-362.

Craig JBL and Lindsay N (2002) Incorporating the family dynamic into the entrepreneurship process, Journal of Small Business and Enterprise Development 9: 416-430.

Craig JBL, Cassar G and Moores K (2006) A 10year longitudinal investigation of strategy, systems, and environment on innovation in family firms, Family Business Review 19: 1-10.

Curimbaba F (2002) The dynamics of women's roles as family business managers, Family Business Review 15: 239-252.

Davis JH, Schoorman FD and Donaldson L (1997) Toward a stewardship theory of management, Academy of Management Review 22(1): 20-47.

Dibrell C and Craig JBL (2006) The natural environment, innovation, and firm performance: A comparative study of family and non-family firms, Family Business Review 31: 275-287.

Dugan AM, Krone SP, LeCouvie K, Pendergast JM, Kenyon-Rouvinez DH and Schuman AM (2008) A Woman's Role: the crucial roles of women in family business. Marietta GA: The Family Business Consulting Group.

Dumas CA (1989) Understanding father-daughter and father-son dyads in family-owned businesses, Family Business Review 2: 31-46.

Dumas CA (1990) Preparing the new CEO: Managing the father-daughter succession process in family businesses, Family Business Review 2: 169-181.

Dumas CA (1992) Integrating the daughter into family business management, Entrepreneurship: Theory \& Practice 16: 41-55.

Eisenhardt K (1989) Building theories from case study research, Academy of Management Journal 14: 532-550.

Evans M (2005) Coutts 2005 Family Business Survey. Accessed 19 July 2008 from http://www.directorbank.com/graphics_uploade d/coutts2005_family_business_survey.pdf.

Fischer E, Reuber AR and Dyke LS (1993) A theoretical overview and extension of research on sex, gender, and entrepreneurship, Journal of Business Venturing 8: 151-168.

Grandori A (2001): Neither hierarchy nor identity: Knowledge-governance mechanisms and the theory of the firm, Journal of Management and Governance 5: 381-399.

Greer MJ and Greene PG (2003) Feminist theory and the study of entrepreneurship. In Butler JE (Ed), New perspectives on women entrepreneurs. Greenwich CT: Information Age Publishing, pp 1-24.

Habbershon TG and Williams ML (1999) A resource-based framework for assessing the strategic advantages of family firms, Family Business Review 12: 1-25.

Hofstede G (1980) Culture's consequences: International differences in work-related values. London: Sage.

Hofstede (1998) Masculinity and femininity: the taboo dimension of national cultures. Thousand Oaks CA: Sage.

Hollander BS and Bukowitz WR (1990) Women, family cultures, and family business, Family Business Review 3: 139-151.

Hurley A (1999) Incorporating feminist theories into sociological theories of entrepreneurship, Women in Management Review 14: 54-62.

Iannarelli CL (1993) The socialization of leaders: A study of gender in family business, Dissertation Abstracts International 53: 3283-3284.

Knight F (1964) [1921] Risk, Uncertainty and Profit. New York: Sentry Press.

Lave J (1988) Cognition in Practice. Cambridge UK: Cambridge University Press.

Lave J and Wenger É (1991) Situated Learning and Peripheral Participation. Cambridge UK: Cambridge University Press.

Litz RA (1995) The family business: toward definitional clarity, Family Business Review 8: 71-81.

Lyman AR (1988) Life in the family cycle, Family Business Review 1: 383-398.

Makino S and Neupert KE (2000) National culture, transaction costs, and the choice between joint venture and wholly owned subsidiary, Journal of International Business Studies 31: 705-713.

Mass Mutual Financial Group (2007) Study: Family businesses growing steady and strong but face future risks: 2007 American Family Business Survey highlights opportunities and challenges for family firms across the US. Press release 1 November 2007. Accessed 8 June 2008 from 
Spotlights and shadows: Preliminary findings about the experiences of women in family business leadership roles

http://www.massmutual.com/mmfg/about/pr_2 007/11_1_2007.html

McGrath R, MacMillan IC and Scheinberg S (1992) Elitists, risk-takers and rugged individualists? An exploratory analysis of cultural differences between entrepreneurs and non-entrepreneurs. Journal of Business Venturing 7(2): 115-135.

Metcalfe BD (2006) Exploring cultural dimensions of gender and management in the Middle East, Thunderbird International Business Review 48: 93-107.

Metcalfe BD (2007) Gender and HRM in the Middle East, International Journal of Human Resource Management 18: 54-75.

Miller D and Le Breton-Miller I (2005) Management insights from great and struggling family businesses, Long Range Planning 38: 517-530.

Mitchell RK, Smith JB, Morse EA, Seawright KW, Peredo AM and McKenzie B (2002) Are entrepreneurial cognitions universal? assessing entrepreneurial cognitions across cultures, Entrepreneurship: Theory \& Practice 26: 9-32.

Moores K and Barrett MA (2002) Learning family business: paradoxes and pathways. Aldershot UK: Ashgate Publishing.

Mueller SL and Thomas AS (2000) Culture and entrepreneurial potential: a nine country study of locus of control and innovativeness, Journal of Business Venturing 16: 51-75.

Nelson T and Levesque LL (2007) The status of women in corporate governance in high-growth, high-potential firms, Entrepreneurship: Theory \& Practice 31: 209-232.

Ogbor JO (2000) Mythicizing and reification in entrepreneurial discourse: ideology critique of entrepreneurial studies, Journal of Management Studies 37: 605-635.

Orr J (1996) Talking about machines: An ethnography of a modern job. Ithaca NY: Cornell University Press.

Ruble DN (1987) The acquisition of selfknowledge: A self-socialization perspective. In N Eisenberg (Ed) Contemporary topics in developmental psychology. New York: Wiley, pp 243-270.

Salganicoff M (1990) Women in family business:
Challenges and opportunities, Family Business Review 3: 125-137.

Semin GR and Zwier SM (1997) Social Cognition. In Berry JW, Segall MH and Kagitcibasi C (Eds), Handbook of cross-cultural psychology Vol 3: Social behavior and applications. Needham Heights MA: Allyn and Bacon, pp 51-76.

Sexton DL and Bowman-Upton N (1990) Female and male entrepreneurs: Psychological characteristics and their role in gender-related discrimination, Journal of Business Venturing 5: 29-36.

Sharma P (2008) Commentary - Familiness: Capital stocks and flows between family and business, Entrepreneurship: Theory \& Practice 34: 971-977.

Silverman D (1985) Qualitative Methodology and Sociology. Hants UK: Gower Publishing.

Sonnenfeld J (1988) The Hero's Farewell: What Happens When CEOs Retire. Oxford UK: Oxford University Press.

Stinchcombe AL (1965) Social structure and organizations. In JG March (Ed) Handbook of Organizations. Chicago: Rand McNally, pp 142-193.

Vera CF and Dean MA (2005) An examination of the challenges daughters face in family business succession, Family Business Review 18: 321-345.

Wenger É (1999) Communities of practice: learning, meaning and identity. Cambridge UK:

Cambridge University Press.

Wenger É (2000) Communities of practice and social learning systems, Organization 7: 225-246.

Westhead P and Cowling M (1998) Family firm research: the need for a methodological rethink, Entrepreneurship: Theory \& Practice 23: 31-56.

Whetten D (1989) What constitutes a theoretical contribution? Academy of Management Review 14: 490-495.

Yin RK (1984) Case study research: design and methods. Beverly Hills CA: Sage.

Zimmerman M and Zeitz G (2002) Beyond survival: Achieving new venture growth by building legitimacy, Academy of Management Review 27: 414-431.

\section{Stability and Change: Managing the Tensions}

Special Issue of Journal of Management \& Organization - Editors: Stephane Tywoniak and Jennifer Bartlett, Queensland University of Technology

Deadline for Papers: 1st February 2010 ISBN 978-1-921348-50-1 ii+126 pages Pub. March 2011 as Vol 17/1 eContent Management Pty Ltd, PO Box 1027, Maleny QLD 4552, Australia

Tel.: +61-7-5435-2900; Fax. +61-7-5435-2911; subscriptions@e-contentmanagement.com www.e-contentmanagement.com 